South Dakota State University

Open PRAIRIE: Open Public Research Access Institutional

Repository and Information Exchange

Agronomy, Horticulture and Plant Science

Department of Agronomy, Horticulture, and

Faculty Publications

Plant Science

$3-2014$

Pre-Plant Anhydrous Ammonia Placement Consequences on No-

Till Versus Conventional-Till Maize Growth and Nitrogen

Responses

Peter Kovacs

George E. Van Scoyoc

Thomas A. Doerge

James J. Camberato

Tony J. Vyn

Follow this and additional works at: https://openprairie.sdstate.edu/plant_faculty_pubs

Part of the Agronomy and Crop Sciences Commons 


\title{
Pre-Plant Anhydrous Ammonia Placement Consequences on No-Till Versus Conventional-Till Maize Growth and Nitrogen Responses
}

\author{
Péter Kovács,* George E. Van Scoyoc, Thomas A. Doerge, James J. Camberato, and Tony J. Vyn*
}

\begin{abstract}
With the advent of precision guidance systems, maize (Zea mays L.) farmers in various tillage systems have more options in preplant nutrient banding relative to the intended crop rows. Anhydrous ammonia $\left(\mathrm{NH}_{3}\right)$ placement during pre-plant application is of interest because of concerns for possible ammonia toxicity to maize seedlings when high $\mathrm{NH}_{3}$ rates are applied too close to the seed row and the need to improve plant-nitrogen $(\mathrm{N})$ use efficiencies. Field studies were conducted between 2010 and 2012 near West Lafayette, IN, to compare traditional angled (diagonally) vs. precision-guided parallel $\mathrm{NH}_{3}$ applications (the latter was offset $15 \mathrm{~cm}$ from the future row) in no-till and conventional tillage systems. The $\mathrm{NH}_{3}$ was injected to depths of about $12 \mathrm{~cm}$ at $\mathrm{N}$ rates of 145 and $202 \mathrm{~kg} \mathrm{~N} \mathrm{ha}^{-1}$. Maize was planted with additional starter $\mathrm{N}\left(20 \mathrm{~kg} \mathrm{~N} \mathrm{ha}^{-1}\right)$ within $6 \mathrm{~d}$ of $\mathrm{NH}_{3}$ application. Neither $\mathrm{NH}_{3}$ application placement resulted in significant maize seedling mortality. Conventional tillage increased mean grain yields across $\mathrm{N}$ rates and placement treatments from 10.6 to $11.6 \mathrm{Mg} \mathrm{ha}^{-1}$. Tillage did not impact reproductive-stage leaf chlorophyll content (SPAD), or whole-plant $\mathrm{N}$ content at maturity when $\mathrm{NH}_{3}$ was parallel applied, but these plant responses were significantly lower in no-till after diagonal application. Lowering the pre-plant $\mathrm{N}$ rate to 145 from $202 \mathrm{~kg} \mathrm{~N} \mathrm{ha}^{-1}$ significantly lowered maize whole-plant biomass and $\mathrm{N}$ accumulation at maturity with diagonal application, but not when $\mathrm{NH}_{3}$ was parallel applied.
\end{abstract}

Today's agriculture faces two major challenges: (i) satisfying the growing food demand of the ever-expanding world population, while (ii) stabilizing or lowering the associated production risks and environmental pollution. Modern maize production relies heavily on $\mathrm{N}$ fertilizer use. Anhydrous ammonia is the most concentrated $\mathrm{N}$ source $(82 \% \mathrm{~N})$ and is one of the most widely applied $\mathrm{N}$ fertilizers in the last few decades in the United States (IFA, 2013) primarily due to its lower cost per unit of $\mathrm{N}$ relative to the cost of other $\mathrm{N}$ sources.

With the advent of precision guidance systems, maize farmers in various tillage systems have more options in pre-plant nutrient banding relative to the intended crop rows. The first concern in $\mathrm{NH}_{3}$ placement during pre-plant applications is possible ammonia toxicity to maize seedlings when high $\mathrm{NH}_{3}$ rates are applied too close in space and time to the future maize rows. Maize farmers in the Midwest region of the United States traditionally apply their pre-plant $\mathrm{NH}_{3}$ at some degree of angle (i.e., diagonally) to the intended maize rows and subsequently use secondary tillage in an attempt to minimize maize stand loss. Approximately 40 to $70 \%$ of spring pre-plant

P. Kovács, G.E. Van Scoyoc, J.J. Camberato, and T.J. Vyn, Purdue Univ., Dep. of Agronomy, West Lafayette, IN 47907; T.A. Doerge, Deere \& Company, Moline, IL 61265. Received 22 July 2013. ${ }^{*}$ Corresponding authors (ppeter. kovacs@gmail.com,tvyn@purdue.edu).

Published in Agron. J. 106:634-644 (2014)

doi:10.2134/agronj2013.0356

Available freely online through the author-supported open access option. Copyright $\odot 2014$ by the American Society of Agronomy, 5585 Guilford Road, Madison, WI 53711. All rights reserved. No part of this periodical may be reproduced or transmitted in any form or by any means, electronic or mechanical, including photocopying, recording, or any information storage and retrieval system, without permission in writing from the publisher. applied $\mathrm{NH}_{3}$ is applied at an angle to the future maize row in the region (T. Doerge, unpublished data, 2013). The second concern is the overall goal of improving plant $\mathrm{N}$ efficiencies, and testing whether that can be promoted by applying lower overall $\mathrm{N}$ rates when the $\mathrm{N}$ fertilizer is parallel applied in close and consistent proximity to the maize row. The third concern is one of integrating pre-plant parallel application with no-till planting systems if newly designed coulter-based applicators achieve less soil disturbance than the deep-shank toolbars used in earlier decades.

A new design of shallow $\mathrm{NH}_{3}$ applicators (John Deere $2510 \mathrm{H}$ Nutrient Applicator), recently introduced to the market (John Deere, 2008), is fundamentally different in operation and nutrient placement than the traditional knife-type $\mathrm{NH}_{3}$ applicators. A single-disk opener system mounted on a highclearance frame places nutrients at a depth of about 10 to $12 \mathrm{~cm}$ instead of the more typical placement depth of 20 to $25 \mathrm{~cm}$. One of the reported advantages of the $2510 \mathrm{H}$ applicators is that the reduced soil disturbance provides more opportunity for farmers to apply $\mathrm{NH}_{3}$ in no-till systems (John Deere, 2013a). Before the commercial development of the Deere $2510 \mathrm{H}$, Hanna et al. (2005) measured higher $\mathrm{NH}_{3}$ losses with shallow $\mathrm{NH}_{3}$ placement using a single-disc opener prototype unit compared to traditional knife-type application to deeper

Abbreviations: \%Nel, ear-leaf nitrogen concentration, ACRE, Agronomy Center for Research and Education, $\mathrm{DM}_{\mathrm{R} 6}$, aboveground biomass production at physiological maturity, $\mathrm{GDU}_{{ }^{\circ} \mathrm{C}}$, Celsius degree based growing degree unit, $\mathrm{GY}_{\mathrm{A}}$, grain yield per unit area, $\mathrm{HI}$, harvest index; $\mathrm{NH}_{3}$, anhydrous ammonia; NHI, nitrogen harvest index, $\mathrm{N}_{\text {total }}$, whole-plant nitrogen uptake at physiological maturity, RTK, real-time kinematic, $\mathrm{Sp}_{x x}$, SPAD readings at $x x$ growth stage, UAN, urea-ammonium-nitrate. 
depth. Nutrient-sealing modifications were made since that time to reduce potential $\mathrm{NH}_{3}$ losses during applications.

Previous studies (Blue and Eno, 1954; Stanley and Smith, 1956; McDowell and Smith, 1958; Sohn and Peech, 1958; Sommer and Christensen, 1992; Hanna et al., 2005) documented that retention of $\mathrm{NH}_{3}$ in the soil following traditional knife-type injection depends on the depth of application, moisture content of the soil, soil texture, and the amount of soil organic matter. Other studies have concluded that gaseous $\mathrm{NH}_{3}$ losses were negligible immediately following application even at higher $\mathrm{N}$ rates at optimum soil (moisture) conditions when depth of $\mathrm{NH}_{3}$ placement was $5 \mathrm{~cm}$ in medium-textured soils, and $10 \mathrm{~cm}$ in coarser-textured soil (Baker et al., 1959; Swart et al., 1971). Optimal soil moisture at the time of application may be more crucial for shallow $\mathrm{NH}_{3}$ placement, and less optimum soil moisture conditions are more likely in sidedress vs. pre-plant applications.

Although there has been extensive engineering testing in the design of the Deere $2510 \mathrm{H}$ applicator (John Deere, 2013a) for the ability to operate in a wide range of soil conditions (such as soil moisture, texture, and different tillage or crop rotation systems), relatively few studies have investigated whether this new applicator improves nutrient use efficiency for $\mathrm{N}$ in modern maize production systems. In fact, few replicated field research studies have been conducted using the $2510 \mathrm{H}$ (John Deere 2013a) applicator in the United States, and none in Indiana. Results of these studies with the $2510 \mathrm{H}$ (John Deere 2013a) are available in graduate theses or in conference proceedings (maize: Sawyer et al., 2009; Stamper, 2009; Fernández et al., 2011; Foster and Mengel, 2012a, wheat [Triticum aestivum L.]: Wyckoff, 2009; Foster and Mengel, 2012b). Some of these studies compared the shallow $\mathrm{NH}_{3}$ placement $(\sim 12 \mathrm{~cm})$ with the deep $\mathrm{NH}_{3}$ placement $(20-25 \mathrm{~cm}$; Sawyer et al., 2009; Stamper, 2009). Certainly, growers would like to better understand the possible consequences of shallow $\mathrm{NH}_{3}$ placements combined with precision guidance.

Placement of $\mathrm{N}$ in general, and $\mathrm{NH}_{3}$ in particular, in close proximity to maize plants has been shown to negatively impact plant growth under some conditions. Sawyer et al. (2009) reported slow maize seedling emergence, severely reduced growth rates, and greater visual damage at higher fertilizer $\mathrm{N}$ rates (179 and $224 \mathrm{~kg} \mathrm{~N} \mathrm{ha}^{-1}$ ), when $\mathrm{NH}_{3}$ was pre-plant applied-with a high-speed, low-disturbance applicator-directly below future maize rows between 7 and $20 \mathrm{~d}$ before planting maize in Iowa. They also observed small but visible reductions in maize growth at the $224 \mathrm{~kg} \mathrm{~N} \mathrm{ha}^{-1}$ rate when $\mathrm{NH}_{3}$ was fall applied in the same below-row position. The early-season delay in development resulted in reduced plant biomass and grain yield per unit area $\left(\mathrm{GY}_{\mathrm{A}}\right)$. However, Stamper (2009) in Kansas did not report seedling injuries with the very same method with supplemental irrigation (timing of irrigation was not published).

With traditional applicators, the degree of injury to maize germination and early growth decreased with increasing application depth or increasing time between pre-plant $\mathrm{NH}_{3}$ application and planting (Colliver and Welch, 1970). Damage to maize seedlings increased with higher $\mathrm{N}$ rates. Toxicity was expressed not only in reduced seedling emergence, but also in plant death following emergence and in stunted growth. Shallow $\mathrm{NH}_{3}$ applicators obviously are limited in their ability to increase application depth. However, increased horizontal separation of the $\mathrm{NH}_{3}$ band from the intended maize row and temporal separation between $\mathrm{NH}_{3}$ application and planting are two ways to enhance crop safety. These two methods were recommended for the shallow nutrient applicator to avoid seedling injuries (Sawyer et al., 2009; Fernández et al., 2011).

Many management factors have been documented that can influence individual plant performance within maize stands; these include planter type (Liu et al., 2004a), delay in seedling emergence and uniformity (Nafziger et al., 1991; Liu et al., 2004b), plant density (Daynard and Muldoon, 1983; Boomsma et al., 2009; Ciampitti and Vyn, 2011; Rossini et al., 2011), low $\mathrm{N}$ rates (Boomsma et al., 2009), and uneven plant spacing (Doerge et al., 2002; Lauer and Rankin, 2004; Liu et al. [2004b, 2004c]; Nielsen, 2006). An additional source of plantto-plant variability can be the placement of $\mathrm{N}$ as this factor affects the time required for the developing plant root system to reach plant-available $\mathrm{N}$ following banded applications.

Recommendations by agronomists (Wagner and Vasey, 1979; Monsanto Technology Development, 2013; Rankin, 2013; Sawyer, 2013) encourage caution with spring pre-plant $\mathrm{NH}_{3}$ application; therefore most farmers and especially those without reliable navigation guidance still apply pre-plant $\mathrm{NH}_{3}$ at some angle (diagonally) to the intended maize row. However, diagonally-applied $\mathrm{NH}_{3}$ can induce visible band effects throughout the field (Zhang et al., 2008b, 2010a, 2010b) reflecting temporary $\mathrm{N}$ deficiency, which can appear as light green strips between the application bands. Diagonal application creates varying distances between maize plants and the nutrient band and thus, depending on soil and environmental factors, maize plants within a row will vary in their access to mineral $\mathrm{N}$ from those bands. For example, plants closer to the $\mathrm{NH}_{3}$ application bands showed advanced development in terms of height and leaf greenness compared to plants farther away from the band in Iowa (Zhang et al., 2008b, 2010a, $2010 b)$. On the other hand, $\mathrm{NH}_{3}$ placement directly under maize plants (such as the intersection of $\mathrm{NH}_{3}$ band and plant row in diagonal application) in some cases turned out to be disadvantageous for plant development (Sawyer et al., 2009; Fernández et al., 2011). These early-stage nutrient advantages and disadvantages could result in less uniform plants within the rows and, perhaps, reductions in final $\mathrm{GY}_{\mathrm{A}}$ and $\mathrm{N}$ uptake.

Tillage system can also be an important factor affecting the uniformity of maize plant growth/development and the uniformity of root access to nutrients (DeFelice et al., 2006). Al-Kaisi and Kwaw-Mensah (2007) found no significant differences between tillage systems on maize yield and $\mathrm{N}$ uptake in Iowa during their manure and fertilizer comparison study. Most tillage-derived differences in crop nutrient status were observed early in the growing season. Vetsch and Randall (2004) observed a $\mathrm{GY}_{\mathrm{A}}$ benefit with conventional tillage compared to no-till system, but they noted that tillage system had minimal effect on measured maize production parameters and no effect on relative yield performance of various $\mathrm{N}$ timing or placement methods. Both Mengel et al. (1982) and Boomsma et al. (2010) found conventional tillage increased grain yield compared to no-till system. The latter study also emphasized the critical importance of maintaining uniform plant heights during vegetative development in no-till maize 
for achieving final yields similar to those with conventional tillage (Boomsma et al., 2010).

Because of the utility and decreasing cost, farmers are increasingly adopting real-time kinematic (RTK) correction for GPS guidance which can repeatedly position tractors to the same position, with $\pm 2 \mathrm{~cm}$ precision (John Deere, 2013b). This technology enables farmers to more confidently place their nutrients parallel to, but potentially at a "safe" distance away from, the maize row to provide all plants consistent accessibility to fertilizers. Maize $\mathrm{GY}_{\mathrm{A}}$ advantages of the RTK system in precise parallel placement of rows 12 to $13 \mathrm{~cm}$ away from pre-plant, coulter-injected urea ammonium-nitrate (UAN) applications at total $\mathrm{N}$ rates up to $224 \mathrm{~kg} \mathrm{~N}^{-1}$ were previously demonstrated in Indiana (Vyn and West, 2009). In that study, maize plant populations declined and $\mathrm{GY}_{\mathrm{A}}$ were reduced (in some cases up to $3.7 \mathrm{Mg} \mathrm{ha}^{-1}$ ) when maize rows were planted right on top of the UAN bands within $24 \mathrm{~h}$ of UAN application to depths of approximately 8 to $10 \mathrm{~cm}$ especially in drier soil conditions and on coarser soil.

To date, no research has evaluated and quantified the effects of pre-plant $\mathrm{NH}_{3}$ application direction, especially diagonal to the future row vs. parallel to maize rows, on maize performance $\left(\mathrm{GY}_{\mathrm{A}}, \mathrm{N}\right.$ uptake, etc.). Effects of $\mathrm{N}$ fertilizer application direction have only been compared in common bean (Phaseolus vulgaris $\mathrm{L}$.), where parallel urea application increased $\mathrm{GY}_{\mathrm{A}}$ (Thung et al., 2007), and in wheat, where no directional effect was found with side-dress $\mathrm{NH}_{3}$ application (Wyckoff, 2009).

The primary objectives of this study were to evaluate whether maize growth, yield, and plant $\mathrm{N}$ acquisition responses to tillage systems or applied $\mathrm{N}$ rates were affected by the direction of shallow pre-plant $\mathrm{NH}_{3}$ applications.

\section{MATERIALS AND METHODS}

\section{Site Description and Experimental Design}

The study was conducted between 2010 and 2012 at Purdue University's Agronomy Center for Research and Education (ACRE) near West Lafayette, IN (40.4853246, -87.0006963). The experiment was established in a maize-soybean [Glycine $\max ($ L.) Merr.] crop rotation where soybean was managed with no-till practices. Three management factors were investigated in a factorial design with six replications: (i) $\mathrm{NH}_{3}$ application direction (traditional diagonal $\mathrm{NH}_{3}$ application to the maize row [at a $15^{\circ}$ angle] vs. parallel application, but $15-\mathrm{cm}$ offset from maize row), (ii) tillage systems (conventional tillage and no-till system), and (iii) applied $\mathrm{N}$ rates $\left\{202 \mathrm{~kg} \mathrm{~N} \mathrm{ha}^{-1}(\mathrm{~N}\right.$ Rate Calculator recommendation for applied cropping system at $\$ 880 \mathrm{Mg}^{-1} \mathrm{NH}_{3}$ and $\$ 197.00 \mathrm{Mg}^{-1}$ maize price level for Indiana [Iowa State University, 2013]) and $145 \mathrm{~kg} \mathrm{~N} \mathrm{ha}^{-1}$. The latter $33 \%$ reduction in $\mathrm{N}$ rate was chosen to determine whether parallel placement would be more advantageous to maize $\mathrm{GY}_{\mathrm{A}}$ and plant $\mathrm{N}$ uptake at lower $\mathrm{N}$ rates; unfortunately, resources were insufficient to compare more than two $\mathrm{N}$ rates. The two $\mathrm{NH}_{3}$ application direction treatments are referred to as diagonal and parallel $\mathrm{NH}_{3}$ application, respectively, in rest of the manuscript. Due to the limited area available for this experiment and the constraints of requiring sufficiently wide "border plots" for equipment turning alongside plots with diagonal $\mathrm{NH}_{3}$ application; treatment assignment followed a randomized complete block design with split-plot arrangement where $\mathrm{NH}_{3}$ application direction was the main factor, and tillage systems and $\mathrm{N}$ rates were the subplots. Subplots were $9.15 \mathrm{~m}$ in width (12 rows) and $68.6 \mathrm{~m}$ in length.

The study was conducted on a Chalmers silty clay loam (finesilty, mixed, superactive, mesic Typic Endoaquoll) soil in 2010 and 2012, and on Drummer silty clay loam (fine-silty, mixed, superactive, mesic Typic Endoaquoll) soils in 2011 with 30 to 40 and 35 to $50 \mathrm{mg} \mathrm{kg}^{-1}$ organic matter content, respectively. Both soils involved in the experiment were poorly drained, but systematically tile drained.

\section{Weather Information}

Daily minimum and maximum air temperatures, and precipitation information was obtained for the growing seasons from an automated weather station operated by the Indiana State Climate Office located about $1 \mathrm{~km}$ from the research sites.

\section{Field Preparation and Planting}

Conventionally tilled plots were chisel-plowed to a $25-\mathrm{cm}$ depth the previous fall of the respective growing seasons. The John Deere 2510H nutrient applicator (John Deere, Moline, IL) consists of a toolbar that was three-point hitch mounted on a dual-wheeled tractor. This applicator was used to pre-plant apply $\mathrm{NH}_{3}$ to a depth of about $12 \mathrm{~cm}$ at the assigned $\mathrm{N}$ rates and directions relative to future maize rows. The applicator was upgraded and equipped with an $\mathrm{NH}_{3}$ Equaply anhydrous delivery system $\left(\mathrm{aNH}_{3}\right.$ Company, Elkhart, IL) in 2011 and 2012. Soil moisture conditions were optimal for $\mathrm{NH}_{3}$ application each year of the study; no visible fumes or strong odors of $\mathrm{NH}_{3}$ escape were noticed during application. One pass of shallow secondary tillage was done following $\mathrm{NH}_{3}$ application in conventional-tilled plots to avoid disturbance of the $\mathrm{NH}_{3}$ band. Maize was planted at 85,000 seeds ha ${ }^{-1}$ rate using a JD1780 six-row planter (John Deere, Moline, IL) equipped with no-till trash-wheel and coulter combinations. Pioneer 1395XR (comparative relative maturity [CRM] $113 \mathrm{~d}$; DuPont Pioneer, Johnston, IA) and 1567XR (CRM 116 d; DuPont Pioneer, Johnston, IA) hybrids were planted in 2010 and 20112012, respectively. Starter fertilizer (10-34-0) was applied at the rate of about $20 \mathrm{~kg} \mathrm{~N} \mathrm{ha}^{-1}$ and about $70 \mathrm{~kg} \mathrm{P}_{2} \mathrm{O}_{5} \mathrm{ha}^{-1}$ using the typical placement of $5 \mathrm{~cm}$ to the side by $5 \mathrm{~cm}$ below the seed at the time of planting. The timing of $\mathrm{NH}_{3}$ applications and other key maize phenological stages (Abendroth et al., 2011) for the respective years are shown in Table 1.

\section{In-Season Morpho-Physiological Plant Measurements}

Intensive individual-plant and plot-level measurements were taken in three of the six replications unless otherwise indicated.

Two "uniformity zones" were selected in every plot from two different rows before seedling emergence for nondestructive in-season measurements on individual plants. Lengths of these zones were $5.3 \mathrm{~m}$ in 2010 and 2011 , and $10.7 \mathrm{~m}$ in 2012. Although date of seedling emergence for each plant was recorded in all uniformity zones, other in-season measurements were performed only on one of the two uniformity zones in each plot during the growing season. Each plant in the uniformity zone targeted for intensive sequential measurements was tagged with a unique barcode. 
Table I. Dates of anhydrous ammonia $\left(\mathrm{NH}_{3}\right)$ application, planting, and key maize phenological growth stages for 2010 through 2012 field experiments near West Lafayette, IN.

\begin{tabular}{llll}
\hline \multicolumn{1}{c}{ Variables } & \multicolumn{1}{c}{2010} & 20I I & 20I2 \\
\hline $\mathrm{NH}_{3}$ application & I3-I4 Apr. & I 2 May & I 2 Apr. \\
Secondary tillage & I6 Apr. & I3 May & I3 Apr. \\
Planting & I7 Apr. & I3 May & I8 Apr. \\
VI5 & 29 June & I4 July & 2 July \\
Silking (RI) & I2 July & 2 I July & 9 July \\
Biomass harvest & 2 I Sept. & - & 19 Sept. \\
Grain harvest & 24 Sept. & 7 Oct. & 2 Oct. \\
\hline
\end{tabular}

Plant populations were estimated by counting the number of plants in four randomly selected $5.3 \mathrm{~m}$ long section of rows in each plot after stand establishment (V3-V4 growth stage). Population assessments were conducted in the center four rows in all six replications.

Leaf chlorophyll content was estimated with a SPAD 502 chlorophyll meter (Minolta Camera Co. Ltd., Osaka, Japan) four times during the season (V10, V15, R1, and R3 stages). Leaf chlorophyll content is closely associated with leaf $\mathrm{N}$ content, and, therefore, SPAD readings have routinely been used as a fast and nondestructive assay to estimate leaf N (Dwyer et al., 1991). Readings were taken near the margin in the mid-zone of the youngest fully-expanded leaf before silking, and from the ear-leaf after pollination, similar to previous studies (Blackmer and Schepers, 1995; Binder et al., 2000). Means of three readings were recorded for each plant in the uniformity zones.

Silk emergence (visible silks) and pollen shedding (extrusion of anthers) were recorded daily in the uniformity zones. Accumulated thermal units from planting were derived for each plant according to their recorded silking and tasseling dates via the method described by Gilmore and Rogers (1958) using 10 and $30^{\circ} \mathrm{C}$ temperature thresholds.

Ear-leaves were removed at silking from 10 consecutive plants outside the uniformity zones to determine nutrient concentrations. Leaves were air-dried at $60^{\circ} \mathrm{C}$ to constant weight, ground and analyzed for $\mathrm{N}$ concentration using the Dumas combustion method by a commercial laboratory (A\&L Great Lakes Laboratories, Fort Wayne, IN).

After reaching physiological maturity, 6 (2010) and 10 (2012) consecutive representative plants were harvested in non-border rows outside the uniformity zones to determine aboveground biomass production $\left(\mathrm{DM}_{\mathrm{R} \sigma}\right)$ and plant $\mathrm{N}$ uptake. Stover and ears were separated, air-dried at $60^{\circ} \mathrm{C}$ to constant weight, and weighed. Plant component samples were ground and analyzed for $\mathrm{N}$ concentrations similarly to the ear-leaf samples. Nutrient uptake was calculated as the product of biomass and nutrient concentrations of each plant fraction. Harvest index (HI) and $\mathrm{N}$ harvest index (NHI) were calculated as the ratios of grain weight and grain $\mathrm{N}$ accumulation, respectively, to total plant biomass and $\mathrm{N}$ accumulation at maturity. Final biomass harvest was not taken in 2011 due to the destructive effects of a hailstorm event during mid-grain fill.

The center six rows of each plot were machine harvested (JD9400 combine John Deere, Moline, IL); grain weight and moisture content were determined and yields were adjusted to $155 \mathrm{~g} \mathrm{~kg}^{-1}$ moisture content.

\section{Statistical Analysis}

Analysis of variance for measured variables was executed using PROC MIXED procedure with SAS 9.2 software (SAS Institute Inc., Cary, NC). Mean separation was accomplished using the least significant difference method with a $P<0.05$.

\section{RESULTS AND DISCUSSION}

\section{Weather Information}

Above normal air-temperatures occurred in all three growing seasons (Fig. 1A-1C) especially during the critical period around kernel set (V15-R2). The rainfall amount was above normal in the first half of the 2010 and 2011 seasons (Fig. 1A, $1 \mathrm{~B}, 1 \mathrm{D})$, while it was below or approximately normal rainfall after that. Excessive early-season rainfall delayed the $\mathrm{NH}_{3}$ application and planting by a month in 2011, and forecasts for even more rain necessitated a decrease in the time interval between the $\mathrm{NH}_{3}$ application and planting to just $1 \mathrm{~d}$ separation (Table 1). A severe hailstorm on 13 Aug. 2011, resulted in substantial leaf shredding and stem lodging/breakage at the late $\mathrm{R} 3$ growth stage. There was a 2 to $3 \mathrm{~d}$ interval between $\mathrm{NH}_{3}$ application and planting in 2010, and a 6-d interval in the much drier spring of 2012. The overall rainfall pattern in 2012 was much different from the first 2 yr of the study (Fig. $1 \mathrm{C}, 1 \mathrm{D})$. Lower than normal precipitation in the beginning of the season (only $33 \%$ of normal rainfall between beginning of April and end of July) was followed by approximately normal rainfall in August and September.

\section{In-Season Observations and Measurements}

Among treatments across $3 \mathrm{yr}$, plant populations differed by a maximum value of 1300 plant ha $^{-1}$ (Table 2 ) and plant populations were identical for the two $\mathrm{NH}_{3}$ application directions. Plant population with parallel $\mathrm{NH}_{3}$ placement at $202 \mathrm{~kg} \mathrm{~N} \mathrm{ha}^{-1}$ in conventional tillage was slightly lower than plant populations with other application direction $\times$ tillage treatment combinations (Table 2). Plant populations were lower in the no-till system in 2011 and 2012 compared to the conventional tillage system within the year $\times$ tillage interaction (Table 2). At the $202 \mathrm{~kg} \mathrm{~N} \mathrm{ha}^{-1}$ rate, plant population was only higher with parallel $\mathrm{NH}_{3}$ placement compared to diagonal $\mathrm{NH}_{3}$ placement in 2012, within the year $\times$ application direction $\times \mathrm{N}$ rate interaction (Table 2). Detectable differences in yield or $\mathrm{N}$ uptake among treatments were not expected from these small plant population changes.

Although previous studies reported substantial injury to single plants, or extended lengths of maize plant rows, when pre-plant $\mathrm{NH}_{3}$ was used as the $\mathrm{N}$ source (Colliver and Welch, 1970; Sawyer et al., 2009; Stamper, 2009), extensive plant damage was not observed in any of the $3 \mathrm{yr}$ regardless of $\mathrm{NH}_{3}$ application direction (Fig. 2). The primary cause of the apparent seedling emergence failure was not investigated. Poor seedling emergence could be due to planting error (missing seed), non-viable seed, soil disease related death, or ammonium salt toxicity. In addition, the visible "band"-effects associated with plant $\mathrm{N}$ deficiencies at various distances from diagonal $\mathrm{NH}_{3}$ application documented earlier by Zhang et al. (2008b, 2010a, 2010b) were not evident in this experiment. In this case, the lack of a visual "N-deficient band" effect is probably due to the use of starter fertilizer which, at the rate of $20 \mathrm{~kg} \mathrm{~N} \mathrm{ha}^{-1}$, 

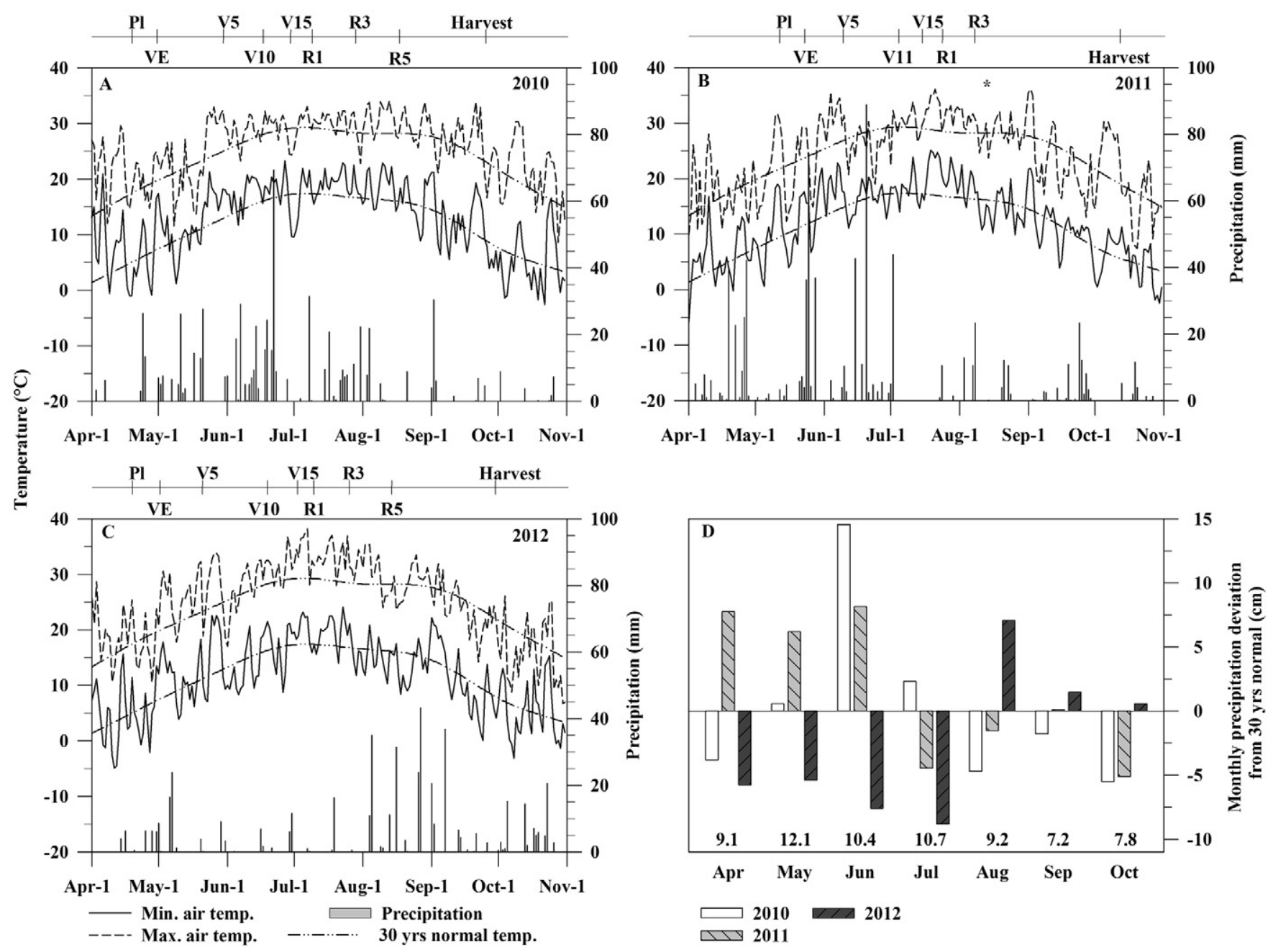

Fig. I. Maximum and minimum air temperature (dashed and solid lines, respectively) and their respective 30-yr normal (dotted line) temperatures and daily precipitation (bars) during the growing season in (A) 2010, (B) 20II, and (C) 2012, and (D) monthly precipitation deviation from the 30-yr normal (198I-20I0; observed at the Indiana State Climate Office's Station near West Lafayette, IN. The 30-yr normal monthly precipitation indicated at the bottom of panel D. Plant development status (Abendroth et al., 20II) is noted above the graphs of each year: PI-seed planting, Harvest-machine harvest. Hail storm event in (B) $201 \mathrm{I}$ marked with the * symbol.

helped to provide sufficient $\mathrm{N}$ for early plant growth $\left(20 \mathrm{~kg} \mathrm{~N} \mathrm{ha}^{-1}\right.$ represents the approximate plant $\mathrm{N}$ accumulation until V6 growth stage) regardless of the plant distance from the concentrated $\mathrm{NH}_{3}$ band. The maize root system also can grow large enough to reach the middle of the row by the V6 stage (Hoeft et al., 2000).

Both tillage system and $\mathrm{N}$ rate significantly affected SPAD readings at mid-silking $\left(\mathrm{Sp}_{\mathrm{R} 1 ;}\right.$ Table 3$)$. Higher SPAD readings were recorded in plots with conventional tillage and at the higher $\mathrm{N}$ rate (Table 4).

Both $\mathrm{NH}_{3}$ application direction $\times$ tillage system and application direction $\times \mathrm{N}$ rate interactions were detected for $\mathrm{Sp}_{\mathrm{R} 3}$ at the $10 \%$ probability level (Table 3 ). The tillage impact for the application direction $\times$ tillage system interaction and the $\mathrm{N}$ rate impact in application direction $\times \mathrm{N}$ rate interactions, respectively, were significant only in diagonal $\mathrm{NH}_{3}$ treatments and tended to reflect smaller changes with parallel $\mathrm{NH}_{3}$ application. When $\mathrm{NH}_{3}$ application direction was compared within tillage system or $\mathrm{N}$ rate, SPAD readings during reproductive stage $\left(\mathrm{Sp}_{\mathrm{R} 3}\right)$ were marginally higher in no-till system, and lower in conventional tillage with parallel $\mathrm{NH}_{3}$ application. Parallel $\mathrm{NH}_{3}$ application resulted in approximately 1.0 unit higher SPAD readings at the lower $\mathrm{N}$ rate during grain fill, but readings were almost the same with this combination at the higher $\mathrm{N}$ rate $\left(202 \mathrm{~kg} \mathrm{~N} \mathrm{ha}^{-1}\right)$. Nitrogen rates, tillage, and year $\times \mathrm{N}$ rate interactions had the biggest impact on ear-leaf $\mathrm{N}$ concentration $\left(\% \mathrm{~N}_{\mathrm{el}}\right.$; Table 3$)$. Higher $\% \mathrm{~N}_{\mathrm{el}}$ at silking were observed in conventional vs. no-tillage plots (Table 4). The year $\times \mathrm{N}$ rate interaction revealed that differences in higher $\% \mathrm{~N}_{\mathrm{el}}$ with higher $\mathrm{N}$ rate was only significant in 2010 and 2011 (Table 5).

Silk emergence was significantly delayed in the no-till system in 2010 and 2012 compared to the conventional tillage system (Table 5). However, delayed silking due to lower $\mathrm{N}$ rate was observed only in 2012 (Table 5).

A minimal difference of SPAD readings in plants grown using the two $\mathrm{NH}_{3}$ application directions is consistent with previous research results (Zhang et al., 2008a, 2009) where authors showed possible limitations of SPAD in identifying moderate $\mathrm{N}$ deficiencies; the $\mathrm{N}$ levels applied in this study (starter $\mathrm{N}$ fertilizer +145 or $202 \mathrm{~kg} \mathrm{~N} \mathrm{ha}^{-1}$ ) would not be expected to severely limit crop growth or $\mathrm{N}$ uptake. In addition, SPAD readings were taken from the ear-leaf where higher $\mathrm{N}$ concentrations are expected to persist longer during grain fill due to its proximity to the sink (Drouet and Bonhomme, 1999, 2004). 
Table 2. Anhydrous ammonia application direction $\times$ tillage system $\times \mathrm{N}$ rate, year $\times$ tillage systems, and year $\times$ application direction $\times \mathrm{N}$ rate interactions effect on plant population in field experiments conducted in 2010 through 2012.

\begin{tabular}{|c|c|c|c|c|}
\hline Year & $\mathrm{NH}_{3}$ application direction & Tillage system & $\mathrm{N}$ rate & Plant population \\
\hline & & & $\mathrm{kg} \mathrm{N} \mathrm{ha}^{-1}$ & plants ha-l \\
\hline \multicolumn{5}{|c|}{ Direction $\times$ Tillage $\times N$ rate } \\
\hline & Diagonal & No-till & 145 & $80,300 \mathrm{ab} \dagger$ \\
\hline & & & 202 & $80,300 \mathrm{ab}$ \\
\hline & & Conventional tillage & 145 & $8 I, 000 a$ \\
\hline & & & 202 & $81,400 a$ \\
\hline & Parallel & No-till & 145 & $79,300 b$ \\
\hline & & & 202 & $80,900 a$ \\
\hline & & Conventional tillage & 145 & $81,600 a$ \\
\hline & & & 202 & $80,900 a$ \\
\hline \multicolumn{5}{|c|}{ Year $\times$ Tillage systems } \\
\hline \multirow[t]{2}{*}{2010} & & No-till & & $82,900 \mathrm{a}$ \\
\hline & & Conventional tillage & & $82,900 \mathrm{a}$ \\
\hline \multirow[t]{2}{*}{2011} & & No-till & & $79,600 c$ \\
\hline & & Conventional tillage & & $80,700 b$ \\
\hline \multirow[t]{2}{*}{2012} & & No-till & & $78,000 d$ \\
\hline & & Conventional tillage & & $80,100 b c$ \\
\hline \multicolumn{5}{|c|}{ Year $\times$ Direction $\times N$ rate } \\
\hline \multirow[t]{4}{*}{2010} & Diagonal & & 145 & $82,700 a$ \\
\hline & & & 202 & $83,600 a$ \\
\hline & Parallel & & 145 & $83,200 a$ \\
\hline & & & 202 & $82,200 \mathrm{ab}$ \\
\hline \multirow[t]{4}{*}{2011} & Diagonal & & 145 & 79,950 cde \\
\hline & & & 202 & $81,000 b c$ \\
\hline & Parallel & & 145 & $79,200 \mathrm{def}$ \\
\hline & & & 202 & $80,500 \mathrm{~cd}$ \\
\hline \multirow[t]{4}{*}{2012} & Diagonal & & 145 & 79,300def \\
\hline & & & 202 & $78,000 f$ \\
\hline & Parallel & & 145 & 78,900 ef \\
\hline & & & 202 & $79,900 \mathrm{cde}$ \\
\hline
\end{tabular}

$\dagger$ Treatment means with different lowercase letters indicate statistically significant differences within the interaction at $P=0.05$.

\section{Grain Yield}

Yield levels were different in each season primarily due to various weather-related limiting conditions (hailstorm, drought); the mid-August hailstorm in 2011 resulted in approximately $2 \mathrm{Mg} \mathrm{ha}^{-1}$ lower $\mathrm{GY}_{\mathrm{A}}$ than 2010 (Table 5). The severe drought of 2012 reduced overall $\mathrm{GY}_{\mathrm{A}}$ even more (by approximately $30 \%$ compared to previous years' mean yields; Table 5). Higher $\mathrm{GY}_{\mathrm{A}}$ was observed in conventional tillage system than in no-till system in each year, but difference between tillage systems was about $1.5 \mathrm{Mg} \mathrm{ha}^{-1}$ in 2010 , while only about $0.8 \mathrm{Mg} \mathrm{ha}^{-1}$ in 2011 and 2012 (Table 5). As expected, $\mathrm{N}$ fertilizer rate also significantly influenced $\mathrm{GY}_{\mathrm{A}}$ (Table 3), but differences between $\mathrm{N}$ rates was almost $1.5 \mathrm{Mg} \mathrm{ha}^{-1}$ in 2010 while the same was only about $0.8 \mathrm{Mg} \mathrm{ha}^{-1}$ in 2011 and 2012 (Table 5). Despite the large differences in $\mathrm{GY}_{\mathrm{A}}$ between the tillage systems and $\mathrm{N}$ rates, $\mathrm{GY}_{\mathrm{A}}$ at the lower $\mathrm{N}$ rate with parallel $\mathrm{NH}_{3}$ placement did not differ from $\mathrm{GY}_{\mathrm{A}}$ attained with the higher $\mathrm{N}$ rate with diagonal $\mathrm{NH}_{3}$ placement; neither did $\mathrm{GY}_{\mathrm{A}}$ with parallel application in the no-till tillage system differ significantly from $\mathrm{GY}_{\mathrm{A}}$ attained in conventional tillage with diagonal application. The lower $\mathrm{N}$ rate lowered $\mathrm{GY}_{\mathrm{A}}$ by
0.8 and $1.2 \mathrm{Mg} \mathrm{ha}^{-1}$ in conventional till and no-till systems, respectively, within the tillage system $\times \mathrm{N}$ rate interaction; however $\mathrm{GY}_{\mathrm{A}}$ for the $145 \mathrm{~kg} \mathrm{~N} \mathrm{ha}^{-1}$ in conventional tillage did not differ significantly from that of the no-till at $202 \mathrm{~kg} \mathrm{~N} \mathrm{ha}^{-1}$ (data not shown).

Higher maize $\mathrm{GY}_{\mathrm{A}}$ in conventional tillage than in no-till was previously reported for Indiana by Barber (1971), Mengel et al. (1982), West et al. (1996), and Boomsma et al. (2010), and for other Corn Belt states by Fink and Wesley (1974), Huggins and Pan (1993), Vetsch and Randall (2004), and Bos (2012). Proportional differences between tillage systems and $\mathrm{N}$ rates were smaller in 2011 and 2012 relative to 2010, presumably as a result of plant growth/grain fill limitations from the hailstorm damage in 2011, and drought stress in 2012 (Eck, 1984; Bennett et al., 1989). The higher leaf chlorophyll content during the grain fill period in both low $\mathrm{N}$ rate and no-till treatments with parallel $\mathrm{NH}_{3}$ application $\left(\mathrm{Sp}_{\mathrm{R} 3}\right.$; Table 6) presumably contributed to slightly higher $\mathrm{GY}_{\mathrm{A}}$ compared to the corresponding treatments that were applied diagonally. 


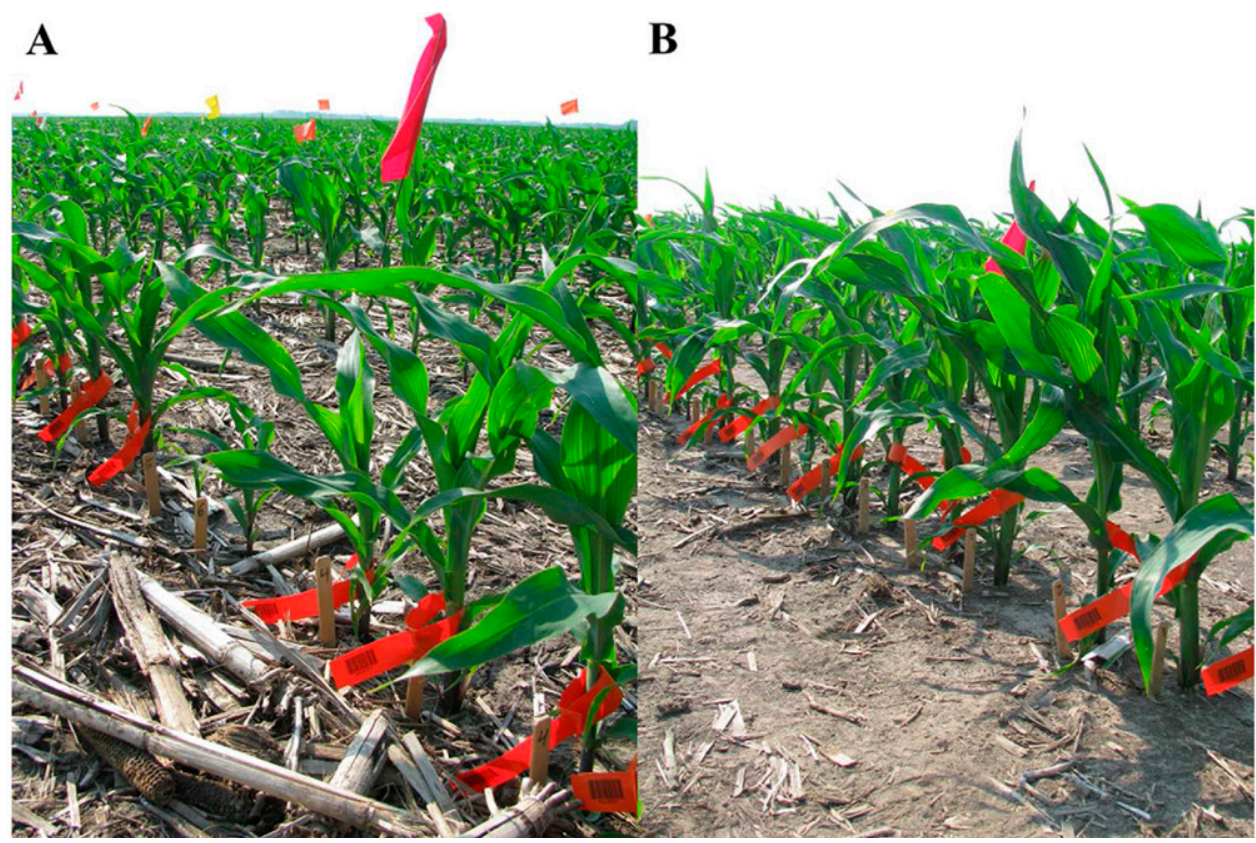

Fig. 2. Effect of anhydrous ammonia $\left(\mathrm{NH}_{3}\right)$ diagonal placement on early plant development near the $\mathrm{NH}_{3}$ band. Flags indicate $\mathrm{NH}_{3}$ band and maize row intersection. (A) Stunted plant growth was randomly observed near $\mathrm{NH}_{3}$ band, but not at every (B) $\mathrm{NH}_{3}$ band intersection.

\section{Biomass and Nutrient Accumulation}

As expected, the higher $\mathrm{N}$ rate resulted in higher $\mathrm{DM}_{\mathrm{R} 6}$ values (Table 6). The lower $\mathrm{N}$ rate significantly reduced $\mathrm{DM}_{\mathrm{R} 6}$ in plots with diagonal $\mathrm{NH}_{3}$ application, but there was no effect of $\mathrm{N}$ rate on $\mathrm{DM}_{\mathrm{R} 6}$ with parallel $\mathrm{NH}_{3}$ application (Fig. 3).

Tillage and $\mathrm{N}$ rate had a significant impact on $\mathrm{HI}$ at the $5 \%$ probability level, while the application direction $\times \mathrm{N}$ rate, and year $\times \mathrm{N}$ rate interactions were significant at the $10 \%$ probability level (Table 3). The HI was significantly higher at the $202 \mathrm{~kg} \mathrm{~N} \mathrm{ha}^{-1}$ rate within diagonal $\mathrm{NH}_{3}$ placement, while
$\mathrm{HI}$ did not differ between $\mathrm{N}$ rates in plots with parallel $\mathrm{NH}_{3}$ placement (Fig. 4). However, the observed variation of HI did not result in any statistical differences in $\mathrm{GY}_{\mathrm{A}}$ at harvest (Table 4). Conventional tillage significantly increased $\mathrm{HI}$ in diagonal $\mathrm{NH}_{3}$ placement, but tillage had no effect with parallel $\mathrm{NH}_{3}$ application. Mean HI was 0.50 in 2010, and about 0.44 in 2012 (data not shown).

The direction of $\mathrm{N}$ placement was found to be crucial at the lower $\mathrm{N}$ rate, where parallel $\mathrm{NH}_{3}$ application resulted in almost $12 \%$ higher $\mathrm{N}_{\text {total }}$, while at the higher $\mathrm{N}$ rate differences

Table 3. Analysis of variance significance levels for treatment effects on various plant and whole plot measurements in 2010 to 2012 field experiments near West Lafayette, IN. Variables include plant population (PLP), silk emergence (Si), ear-leaf $\mathrm{N}$ concentration at silking $\left(\% \mathrm{~N}_{\mathrm{el}}\right)$, SPAD readings at RI and $\mathrm{R} 3$ stages $\left(\mathrm{SP}_{\mathrm{R}_{1}}, \mathrm{SP}_{\mathrm{R}_{3}}\right)$, combine harvested yield $\left(\mathrm{GY}_{\mathrm{A}}\right)$, total biomass production (DM $\left.\mathrm{R}_{6}\right)$, grain harvest index $(\mathrm{HI})$, grain nitrogen concentration $\left(\% \mathrm{~N}_{\mathrm{gr}}\right)$, total whole-plant nitrogen uptake $\left(\mathrm{N}_{\text {total }}\right)$, and nitrogen harvest index $(\mathrm{NHI})$. Data marked with $\ddagger$ indicates that statistical analysis were based on six replications; otherwise it was based on three replications.

\begin{tabular}{|c|c|c|c|c|c|c|c|c|c|c|c|}
\hline \multirow[b]{2}{*}{ Variables } & \multicolumn{6}{|c|}{$2010-2012$} & \multicolumn{5}{|c|}{2010,2012} \\
\hline & PLP & $\mathrm{Si}$ & $\% \mathrm{~N}_{\mathrm{el}}$ & $S P_{R I}$ & $\mathrm{SP}_{\mathrm{R} 3}$ & $G Y_{A} \ddagger$ & $D M_{R 6}$ & $\mathrm{HI}$ & $\mathrm{N}_{\text {total }}$ & $\% \mathrm{~N}_{\mathrm{gr}}$ & $\mathrm{NHI}$ \\
\hline Year $(Y)$ & $* * *$ & $*$ & $* *$ & $* *$ & $*$ & $* * *$ & $* * *$ & $*$ & nst & $* * *$ & $\ddagger$ \\
\hline Direction (D) & ns & ns & ns & ns & ns & ns & ns & ns & ns & ns & ns \\
\hline Tillage (TS) & $* *$ & $* * *$ & $* *$ & $* *$ & $* * *$ & $* * *$ & ns & $*$ & ns & ns & ns \\
\hline N Rate (NR) & ns & $\ddagger$ & $* * *$ & $* *$ & $* * *$ & $* * *$ & $* * *$ & $* *$ & $* * *$ & ns & $* *$ \\
\hline $\mathrm{D} \times \mathrm{TS}$ & ns & ns & ns & ns & $\ddagger$ & ns & $*$ & ns & ns & ns & $\ddagger$ \\
\hline$D \times N R$ & ns & ns & ns & ns & $\ddagger$ & ns & $* *$ & $\ddagger$ & $* *$ & ns & $\ddagger$ \\
\hline $\mathrm{TS} \times \mathrm{NR}$ & ns & ns & ns & ns & ns & $*$ & ns & ns & ns & ns & ns \\
\hline $\mathrm{D} \times \mathrm{TS} \times \mathrm{NR}$ & $*$ & ns & ns & ns & ns & ns & ns & ns & ns & ns & ns \\
\hline$Y \times D$ & ns & ns & ns & ns & ns & ns & ns & ns & ns & $\ddagger$ & ns \\
\hline $\mathrm{Y} \times \mathrm{TS}$ & $*$ & $* * *$ & ns & ns & ns & $*$ & ns & ns & ns & ns & ns \\
\hline $\mathrm{Y} \times \mathrm{D} \times \mathrm{TS}$ & ns & ns & ns & ns & ns & ns & ns & ns & ns & ns & ns \\
\hline$Y \times N R$ & ns & $*$ & $* *$ & ns & ns & $* *$ & ns & $\ddagger$ & ns & $*$ & ns \\
\hline$Y \times D \times N R$ & $*$ & ns & ns & ns & ns & ns & ns & ns & ns & ns & $*$ \\
\hline $\mathrm{Y} \times \mathrm{TS} \times \mathrm{NR}$ & ns & ns & ns & ns & ns & ns & ns & ns & $\ddagger$ & ns & ns \\
\hline $\mathrm{Y} \times \mathrm{D} \times \mathrm{TS} \times \mathrm{NR}$ & ns & ns & ns & ns & ns & ns & ns & ns & ns & ns & ns \\
\hline
\end{tabular}

$* P<0.05$.

$* * P<0.01$.

$* * * P<0.001$.

$\dagger \mathrm{ns}$, not significant.

$\ddagger$ Significant at $P=0.1$. 
Table 4. Effect of shallow anhydrous ammonia placement on plant population, silk emergence (Si), ear-leaf $\mathrm{N}$ concentration (\% $\mathrm{N}_{\mathrm{el}}$ ), SPAD reading at $\mathrm{RI}$ and $\mathrm{R} 3\left(\mathrm{~S}_{\mathrm{P}_{\mathrm{R} I}}, \mathrm{~S}_{\mathrm{P}_{\mathrm{R} 3}}\right)$, and combine harvested grain yield $\left(\mathrm{GY}_{\mathrm{A}}\right)$ using different tillage systems and $\mathrm{N}$ rates in field experiments conducted in 2010 through 2012. Data marked with $\ddagger$ indicates that statistical analysis were based on six replications otherwise it was based on three replications.

\begin{tabular}{|c|c|c|c|c|c|c|}
\hline Treatment & Population & $\mathrm{Si}$ & $\% \mathrm{~N}_{\mathrm{el}}$ & $S P_{R I}$ & $\mathrm{SP}_{\mathrm{R} 3}$ & $\mathrm{GY}_{\mathrm{A}} \ddagger$ \\
\hline & plants ha ${ }^{-1}$ & ${ }_{G D U}^{\circ} \mathrm{C}$ & $g \mathrm{~kg}^{-1}$ & & & $\mathrm{Mg} \mathrm{ha}^{-1}$ \\
\hline \multicolumn{7}{|l|}{ Application direction (D) } \\
\hline Diagonal & $80,700 \dagger$ & 794 & 27.1 & 52.4 & 51.6 & 10.96 \\
\hline RTK & 80,600 & 796 & 27.4 & 52.7 & 52.2 & 11.28 \\
\hline \multicolumn{7}{|l|}{ Tillage system (TS) } \\
\hline No-till (NT) & $80,200 b$ & $815 a$ & $26.8 b$ & $51.9 b$ & 51.16 & $10.62 b$ \\
\hline Conventional till (T) & $81,200 a$ & $775 b$ & $27.7 \mathrm{a}$ & $53.2 \mathrm{a}$ & $52.7 \mathrm{a}$ & $11.6 \mathrm{la}$ \\
\hline \multicolumn{7}{|l|}{$\mathrm{N}$ rate $(\mathrm{NR})$} \\
\hline $145 \mathrm{~kg} \mathrm{~N} \mathrm{ha}{ }^{-1}$ & 80,500 & 798 & $26.5 b$ & $52.0 \mathrm{~b}$ & $50.9 b$ & $10.64 b$ \\
\hline $202 \mathrm{~kg} \mathrm{~N} \mathrm{ha}{ }^{-1}$ & 80,900 & 791 & $27.9 a$ & 53.1a & $52.8 \mathrm{a}$ & II.59a \\
\hline \multicolumn{7}{|l|}{$\mathrm{D} \times \mathrm{TS}$} \\
\hline Diagonal-NT & $80,300 b$ & $813 a$ & $26.6 b$ & $51.5 b$ & $50.5 b$ & $10.52 c$ \\
\hline Parallel-NT & $80,100 \mathrm{~b}$ & $816 a$ & $27.0 \mathrm{ab}$ & $52.4 \mathrm{ab}$ & $51.7 \mathrm{ab}$ & $10.73 \mathrm{bc}$ \\
\hline Diagonal-T & $81,200 a$ & $774 b$ & $27.5 \mathrm{ab}$ & $53.3 \mathrm{a}$ & $52.7 \mathrm{a}$ & II.39ab \\
\hline Parallel-T & $81,200 a$ & $775 b$ & $27.8 \mathrm{a}$ & 53. Iab & $52.6 \mathrm{ab}$ & II.82a \\
\hline \multicolumn{7}{|l|}{$D \times N R$} \\
\hline Diagonal- I45N & 80,600 & $800 a$ & $26.4 b$ & $51.6 b$ & $50.3 c$ & $10.42 c$ \\
\hline Parallel-145N & 80,400 & $796 a b$ & $26.7 b$ & $52.4 \mathrm{ab}$ & $51.6 \mathrm{bc}$ & $10.86 \mathrm{bc}$ \\
\hline Diagonal-202N & 80,800 & $788 b$ & $27.7 a$ & $53.1 \mathrm{a}$ & $52.9 \mathrm{ab}$ & I I.49ab \\
\hline Parallel-202N & 80,900 & $795 a b$ & $28.1 \mathrm{a}$ & $53.0 \mathrm{ab}$ & $52.7 \mathrm{a}$ & $11.69 \mathrm{a}$ \\
\hline
\end{tabular}

$\dagger$ Means within each main factor or interaction followed by different lowercase letters are different at $P=0.05$.

were not observed in $\mathrm{N}_{\text {total }}$ in the application direction $\times \mathrm{N}$ rate interaction (Fig. 3).

Significantly higher grain $\mathrm{N}$ concentrations $\left(\% \mathrm{~N}_{\mathrm{gr}}\right)$ were observed in conventionally tilled plots in 2010 , while no difference was observed between tillage systems in 2012 (Tables 3 and 5).
Year $\times$ application direction $\times \mathrm{N}$ rate interaction significantly impacted $\mathrm{N}$ harvest index (NHI; Table 3); and $\mathrm{NH}_{3}$ application direction $\times$ tillage system and application direction $\times \mathrm{N}$ rate interactions for NHI were also significant at the $10 \%$ probability level $(P=0.09$ and $P=0.09$ respectively;

Table 5. Effect of shallow anhydrous ammonia placement on ear-leaf $\mathrm{N}$ concentration at mid-silking (\% $\left.\mathrm{N}_{\mathrm{el}}\right)$, on silk emergence (Si), combine harvested grain yield $(\mathrm{GY})$, grain $\mathrm{N}$ concentration $\left(\% \mathrm{~N}_{\mathrm{gr}}\right)$, and nitrogen harvest index $(\mathrm{NHI})$ using different tillage systems and $\mathrm{N}$ rates in field experiments conducted in 2010 through 2012. Data marked with $\neq$ indicates that statistical analysis were based on six replications otherwise it was based on three replications.

\begin{tabular}{|c|c|c|c|c|c|}
\hline Treatment & $\% \mathrm{~N}_{\mathrm{el}}$ & $\mathrm{Si}$ & $\mathrm{GY}_{\mathrm{A}} \ddagger$ & $\% \mathrm{~N}_{\mathrm{gr}}$ & $\mathrm{NHI}$ \\
\hline & $\mathrm{g} \mathrm{kg}^{-1}$ & GDU॰C & $\mathrm{Mg} \mathrm{ha}^{-1}$ & $\mathrm{~g} \mathrm{~kg}^{-1}$ & $\mathrm{~kg} \mathrm{~kg}^{-1}$ \\
\hline \multicolumn{6}{|l|}{ Year $\times N$ rate } \\
\hline $2010-145 \mathrm{~N}$ & $24.8 c t$ & $812 a b$ & $12.77 b$ & $\mathrm{II} .7 \mathrm{~b}$ & \\
\hline $2010-202 \mathrm{~N}$ & $27.5 b$ & $814 a b$ & $14.19 \mathrm{a}$ & $12.0 \mathrm{~b}$ & \\
\hline $20 I I-145 N$ & $29.1 \mathrm{~b}$ & $768 c$ & $1 \mathrm{I} .08 \mathrm{c}$ & - & \\
\hline $201 \mathrm{I}-202 \mathrm{~N}$ & $30.3 a$ & $767 c$ & II.86b & - & \\
\hline $2012-145 N$ & $25.8 c$ & $814 a$ & $8.08 \mathrm{e}$ & $16.1 \mathrm{a}$ & \\
\hline $2012-202 \mathrm{~N}$ & $25.9 c$ & $793 b c$ & $8.72 d$ & $15.6 \mathrm{a}$ & \\
\hline \multicolumn{6}{|l|}{ Year $\times$ Tillage system } \\
\hline 20I0-NT & & $826 a$ & $12.79 b$ & $1 \mathrm{I} .2 \mathrm{c}$ & \\
\hline 2010-T & & $800 \mathrm{~b}$ & $14.16 \mathrm{a}$ & $12.5 b$ & \\
\hline 20II-NT & & $773 c$ & $11.06 c$ & - & \\
\hline $201 \mathrm{I}-\mathrm{T}$ & & $762 c$ & I I.88b & - & \\
\hline 20I2-NT & & $846 a$ & $8.02 e$ & $16.0 \mathrm{a}$ & \\
\hline $2012-\mathrm{T}$ & & $76 \mathrm{lc}$ & $8.79 \mathrm{~d}$ & $15.7 \mathrm{a}$ & \\
\hline \multicolumn{6}{|l|}{ Year $\times$ Direction $\times N$ rate } \\
\hline 20I0-Diagonal-I45N & & & & & $0.56 a$ \\
\hline $2010-D i a g o n a l-202 \mathrm{~N}$ & & & & & $0.58 \mathrm{a}$ \\
\hline $2010-P a r a l l e l-145 \mathrm{~N}$ & & & & & $0.58 \mathrm{a}$ \\
\hline $2010-P a r a l l e l-202 \mathrm{~N}$ & & & & & $0.6 \mathrm{la}$ \\
\hline 20I2-Diagonal-I45N & & & & & $0.43 b$ \\
\hline 20I2-Diagonal-202N & & & & & $0.56 a$ \\
\hline 20I2-Parallel-I45N & & & & & $0.52 \mathrm{ab}$ \\
\hline 20I2-Parallel-202N & & & & & $0.53 \mathrm{ab}$ \\
\hline
\end{tabular}

† Means within each main factor or interaction followed by different lowercase letters are different at $P=0.05$. 


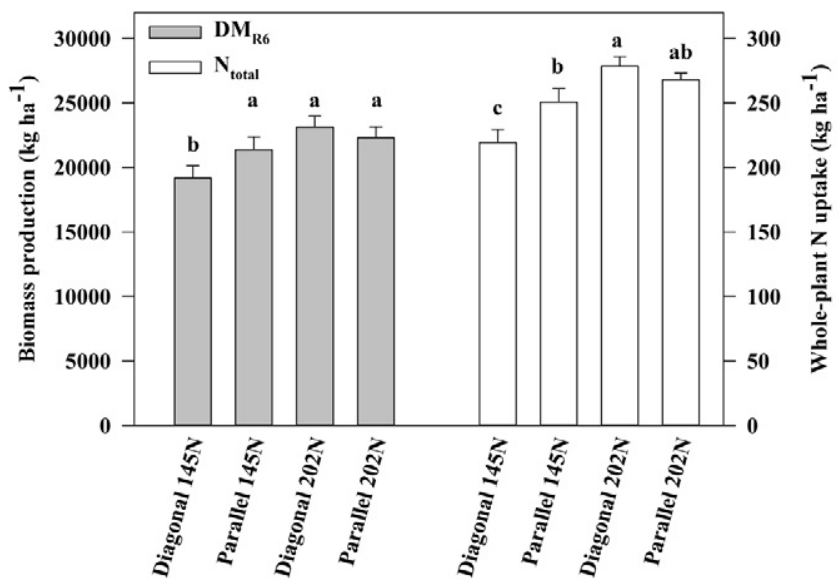

Fig. 3. Effect of anhydrous ammonia placement and applied $\mathrm{N}$ rates on whole-plant biomass production $\left(\mathrm{DM}_{\mathrm{R} 6}\right)$ and $\mathrm{N}$ uptake $\left(\mathrm{N}_{\text {total }}\right)$. Error bars present standard errors. Different lowercase letters indicate statistically significant differences between treatments.

Table 3). Within year $\times$ application direction $\times \mathrm{N}$ rate interaction treatment responses did not differ in 2010 (Table 6). However, within the diagonal $\mathrm{NH}_{3}$ placement in 2012 the $145 \mathrm{~kg} \mathrm{~N} \mathrm{ha}^{-1}$ rate lowered NHI by about $22 \%$ compared to the $202 \mathrm{~kg} \mathrm{~N} \mathrm{ha}^{-1}$ rate. Similar to HI, NHI did not differ between tillage systems with parallel $\mathrm{NH}_{3}$ placement, but differed with diagonal $\mathrm{NH}_{3}$ placement in the application direction $\times$ tillage system interaction (Table 6 ). In the direction $\times \mathrm{N}$ rate interaction, lowering $\mathrm{N}$ rate did not impact $\mathrm{NHI}$ with parallel $\mathrm{NH}_{3}$ placement, while NHI was significantly reduced with diagonal $\mathrm{NH}_{3}$ application (Fig. 4).

The advantages of parallel $\mathrm{NH}_{3}$ application on $\mathrm{HI}$ between tillage systems and $\mathrm{N}$ rates were also observed in leaf chlorophyll content during grain fill $\left(\mathrm{S}_{\mathrm{P}_{3}}\right.$; Table 4$)$, suggesting greater photosynthetic activity during reproductive stages and contribution to ear dry matter accumulation (Tollenaar and Lee, 2010). Overall, HI was lower in 2012 compared to 2010 (Table 5) due to heat and drought stress that reduced kernel set (data not shown) during pollination in 2012. Similar results were reported

Table 6. Effect of shallow anhydrous ammonia placement on whole season aboveground biomass production $\left(\mathrm{DM}_{\mathrm{R} 6}\right)$, harvest index $(\mathrm{HI})$, total whole-plant $\mathrm{N}$ uptake ( $\left.\mathrm{N}_{\text {total }}\right)$, and nitrogen harvest index (NHI) using different tillage systems and $\mathrm{N}$ rates in 2010 and 2012.

\begin{tabular}{|c|c|c|c|c|}
\hline Treatment & $\mathrm{DM}_{\mathrm{R} 6}$ & $\mathrm{HI}$ & $\mathrm{N}_{\text {total }}$ & $\mathrm{NHI}$ \\
\hline & $\mathrm{Mg} \mathrm{ha}^{-1}$ & $\mathrm{~kg} \mathrm{~kg}^{-1}$ & $\mathrm{~kg} \mathrm{ha}^{-1}$ & $\mathrm{~kg} \mathrm{~kg}^{-1}$ \\
\hline \multicolumn{5}{|c|}{ Application direction (D) } \\
\hline Diagonal & $21.4 \dagger$ & 0.46 & 254 & 0.53 \\
\hline Parallel & 22.1 & 0.48 & 263 & 0.56 \\
\hline \multicolumn{5}{|l|}{ Tillage systems (TS) } \\
\hline No-till (NT) & 21.7 & $0.46 \mathrm{~b}$ & 255 & 0.54 \\
\hline Conventional till ( $\mathrm{T}$ ) & 21.8 & $0.49 a$ & 262 & 0.56 \\
\hline \multicolumn{5}{|l|}{ N Rate (NR) } \\
\hline $145 \mathrm{~kg} \mathrm{~N} \mathrm{ha}{ }^{-1}$ & $20.6 b$ & $0.45 b$ & 240 & $0.53 b$ \\
\hline $202 \mathrm{~kg} \mathrm{~N} \mathrm{ha}^{-1}$ & $23.099 a$ & $0.49 a$ & 277 & $0.57 \mathrm{a}$ \\
\hline \multicolumn{5}{|l|}{$\mathrm{D} \times \mathrm{TS}$} \\
\hline Diagonal-NT & 20.8 & $0.44 b$ & 248 & $0.5 \mathrm{Ib}$ \\
\hline Parallel-NT & 22.6 & $0.47 a b$ & 262 & $0.56 \mathrm{ab}$ \\
\hline Diagonal-T & 22.0 & $0.48 a$ & 260 & $0.56 a$ \\
\hline Parallel-T & 21.6 & $0.49 \mathrm{ab}$ & 264 & $0.56 \mathrm{ab}$ \\
\hline
\end{tabular}

† Means within each main factor or interaction followed by different lowercase letters are different at $P=0.05$.

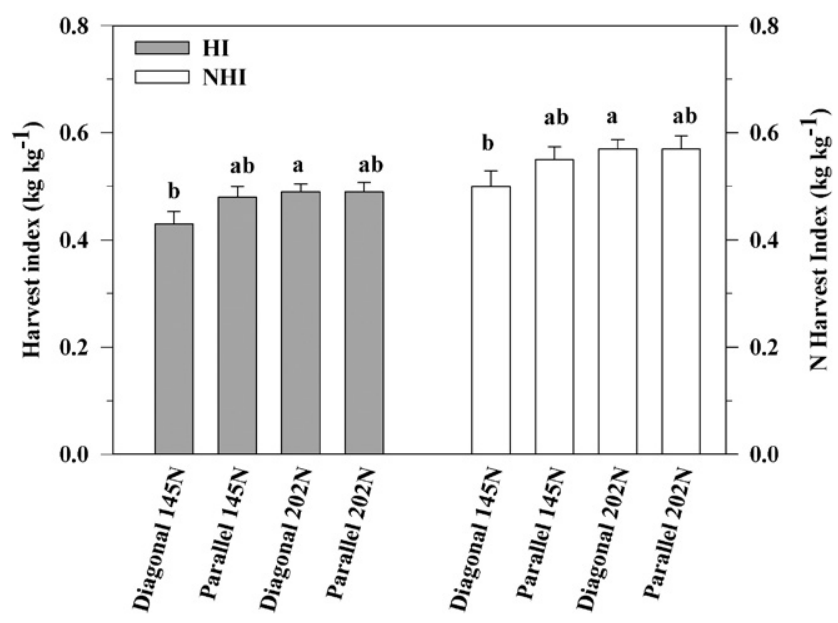

Fig. 4. Effect of anhydrous ammonia placement and applied $\mathrm{N}$ rates on grain harvest index $(\mathrm{HI})$ and nitrogen harvest index $(\mathrm{NHI})$. Error bars present standard errors. Different lowercase letters indicate statistically significant differences between treatments.

by Westgate and Boyer (1985), NeSmith and Ritchie (1992), Schussler and Westgate (1994), and Roth et al. (2013).

The absence of application direction effects on $\mathrm{N}_{\text {total }}$ at the higher $\mathrm{N}$ rate is presumably because this $\mathrm{N}$ rate supplied adequate $\mathrm{N}$ to all plants regardless of proximity to the $\mathrm{NH}_{3}$ bands. Greater plant $\mathrm{N}$ accumulation was observed with parallel $\mathrm{NH}_{3}$ placement in the no-till system, and at the $145 \mathrm{~kg} \mathrm{~N} \mathrm{ha}^{-1}$ rate, compared to the same direction and $\mathrm{N}$ rate treatments with diagonal $\mathrm{NH}_{3}$ application. Also, reducing the $\mathrm{N}$ rate had less deleterious impact on plant $\mathrm{DM}_{\mathrm{R} 6}$, and $\mathrm{N}_{\text {total }}$ when $\mathrm{NH}_{3}$ was parallel applied. Similarly, the reduced $\mathrm{N}$ rate had less impact on ear-leaf chlorophyll content $\left(\mathrm{Sp}_{\mathrm{R} 3}\right)$ in parallel $\mathrm{NH}_{3}$ placement treatments during maize reproductive growth (Table 4). The smaller impact of $\mathrm{N}$ rate reduction with parallel $\mathrm{NH}_{3}$ application suggests that the risk of yield loss from reduced $\mathrm{N}$ rates is less when $\mathrm{N}$ is precision applied in a consistent and "safe" proximity to maize rows.

However, in $2012 \mathrm{~N}$ accumulations $\left(\% \mathrm{~N}_{\mathrm{el}}, \mathrm{N}_{\text {total }}\right)$ with parallel $\mathrm{NH}_{3}$ application were lower in the conventional tillage system compared to no-till system (data not shown). Parallel $\mathrm{NH}_{3}$ application at $202 \mathrm{~kg} \mathrm{~N} \mathrm{ha}^{-1}$ rate resulted also in lower $\% \mathrm{~N}_{\mathrm{el}}$ and $\mathrm{N}_{\text {total }}$ compared to the lower $\mathrm{N}$ rate (data not shown). These reductions in $\mathrm{N}$ utilization suggests that the $15-\mathrm{cm}$ horizontal $\mathrm{NH}_{3}$ band displacement from the maize row may have been too close in conventional tillage and at the $202 \mathrm{~kg} \mathrm{~N} \mathrm{ha}^{-1}$ rate during the dry season of 2012 .

\section{SUMMARY AND CONCLUSION}

Overall maize plant damage was minimal from shallow preplant $\mathrm{NH}_{3}$ placement in either no-till or conventional tillage systems, even when application occurred within $6 \mathrm{~d}$ of planting. More damage may have occurred if $\mathrm{NH}_{3}-\mathrm{N}$ had been injected right under the future maize row, as in other studies (Sawyer et al., 2009; Fernández et al., 2011).

The RTK-guided parallel $\mathrm{NH}_{3}$ application improved plant $\mathrm{N}$ status during reproductive growth $\left(\% \mathrm{~N}_{\mathrm{el}}, \mathrm{Sp}_{\mathrm{R} 3}\right.$; Table 4$)$, and at the low $\mathrm{N}$ rate $\mathrm{N}$ uptake at maturity $\left(\mathrm{N}_{\text {total }}\right.$; Table 6 , Fig. 3), relative to the traditional diagonal pre-plant $\mathrm{NH}_{3}$ application. Parallel, but offset from the row $\mathrm{NH}_{3}$ placement, 
only marginally increased $\mathrm{GY}_{\mathrm{A}}$ compared to the diagonally placed treatments- $<0.45 \mathrm{Mg} \mathrm{ha}^{-1}$. Yield increases with parallel placement compared to diagonal placement were greatest in the no-till system and the lowest $\mathrm{N}$ rate $\left(145 \mathrm{~kg} \mathrm{~N} \mathrm{ha}^{-1}\right)$.

We suggest that application of starter fertilizer, which is still common in Indiana, may have decreased the differences in response between the directional treatments. Larger differences, and higher benefits, would be expected from parallel pre-plant $\mathrm{NH}_{3}$ placement compared to diagonal application if maize is planted without starter N. However, we are still concerned about the spatial-temporal separation between $\mathrm{NH}_{3}$ application and planting especially at high $\mathrm{N}$ rates (more than $200 \mathrm{~kg} \mathrm{~N} \mathrm{ha}^{-1}$ ). Further research should determine the "safe" distance of shallow spring pre-plant $\mathrm{NH}_{3}$ application (especially at high rates) from intended maize rows where yield benefits are still observed, but where crop stunting can be avoided due to dry conditions following $\mathrm{N}$ applications. Future studies are also warranted to identify the minimum time interval between $\mathrm{NH}_{3}$ application and maize planting with different $\mathrm{NH}_{3}$ placements relative to maize rows on less forgiving soils.

\section{ACKNOWLEDGMENTS}

We would like to express our thanks to Deere \& Company for the funding of the experiment, for providing implements and RTK guidance, and especially for the equipment operation assistance provided by Brian Childs and Jamie Bultemeier. Special thanks to the crew of the Purdue Agronomy Farm for their help during field operations. In addition, we would like to thank Terry D. West and Alicia West and the Cropping Systems Research Group's former and recent graduate, undergraduate, and visitor student workers for their involvement during data collection both in the field and in the lab. DuPont Pioneer Hi-Bred International, Inc. provided seed for the experiments.

\section{REFERENCES}

Abendroth, L.J., R.W. Elmore, M.J. Boyer, and S.K. Marlay. 2011. Corn growth and development. PMR 1009. Iowa State Univ. Ext., Ames.

Al-Kaisi, M., and D. Kwaw-Mensah. 2007. Effect of tillage and nitrogen rate on corn yield and nitrogen and phosphorus uptake in a corn-soybean rotation. Agron. J. 99:1548-1558.

Baker, J.H., M. Peech, and R.B. Musgrave. 1959. Determination of application losses of anhydrous ammonia. Agron. J. 51:361-362. doi:10.2134/agronj $1959.00021962005100060016 x$

Barber, S.A. 1971. Effect of tillage practice on corn root distribution and morphology. Agron. J. 63:724-726. doi:10.2134/agronj1971.00021962006 300050020x

Bennett, J.M., L.S.M. Mutti, P.S.C. Rao, and J.W. Jones. 1989. Interactive effects of nitrogen and water stresses on biomass accumulation, nitrogen uptake, and seed yield of maize. Field Crops Res. 19:297-311. doi:10.1016/0378-4290(89)90100-7

Binder, D.L., D.H. Sander, and D.T. Walters. 2000. Maize response to time of nitrogen application as affected by level of nitrogen deficiency. Agron. J. 92:1228-1236. doi:10.2134/agronj2000.9261228x

Blackmer, T.M., and J.S. Schepers. 1995. Use of a chlorophyll meter to monitor nitrogen status and schedule fertigation for corn. J. Prod. Agric. 8:5660. doi:10.2134/jpa1995.0056

Blue, W.G., and C.F. Eno. 1954. Distribution and retention of anhydrous ammonia in sandy soils. Soil Sci. Soc. Am. J. 18:420-424. doi:10.2136/ sssaj1954.03615995001800040017x

Boomsma, C.R., J.B. Santini, M. Tollenaar, and T.J. Vyn. 2009. Maize morpho-physiological responses to intense crowding and low nitrogen availability: An analysis and review. Agron. J. 101:1426-1452. doi:10.2134/ agronj2009.0082

Boomsma, C.R., J.B. Santini, T.D. West, J.C. Brewer, L.M. McIntyre, and T.J. Vyn. 2010. Maize grain yield responses to plant height variability resulting from crop rotation and tillage system in a long-term experiment. Soil Tillage Res. 106:227-240. doi:10.1016/j.still.2009.12.006
Bos, A. 2012. Maize management effect on plant-to-plant variability and grain yield. MSc thesis. The Univ. of Guelph. Guelph, ON, Canada.

Ciampitti, I.A., and T.J. Vyn. 2011. A comprehensive study of plant density consequences on nitrogen uptake dynamics of maize plants from vegetative to reproductive stages. Field Crops Res. 121:2-18. doi:10.1016/j. fcr.2010.10.009

Colliver, G.W., and L.F. Welch. 1970. Toxicity of preplant anhydrous ammonia to germination and early growth of corn: I. Field Studies. Agron. J. 62:341-346. doi:10.2134/agronj1970.00021962006200030009x

Daynard, T.B., and J.F. Muldoon. 1983. Plant-to-plant variability of maize plants grown at different densities. Can. J. Plant Sci. 63:45-59. doi:10.4141/cjps83-005

DeFelice, M.S., P.R. Carter, and S.B. Mitchell. 2006. Influence of tillage on corn and soybean yield in the United States and Canada. www. plantmanagementnetwork.org/cm/. Crop Manage. doi: 10.1094/ CM-2006-0626-01-RS.

Doerge, T., T. Hall, and D. Gardner. 2002. New research confirms benefits of improved plant spacing in corn. Crop insights 12(2). Virginia Tech Univ. http://bsesrv214.bse.vt.edu/Grisso/Ext/Plant_Spacing_in_Corn.doc (accessed 9 Jan 2013).

Drouet, J.-L., and R. Bonhomme. 1999. Do variations in local leaf irradiance explain changes to leaf nitrogen within row maize canopies? Ann. Bot. (Lond.) 84:61-69. doi:10.1006/anbo.1999.0890

Drouet, J.-L., and R. Bonhomme. 2004. Effect of 3D nitrogen, dry mass per area and local irradiance on canopy photosynthesis within leaves of contrasted heterogeneous maize crops. Ann. Bot. (Lond.) 93:699-710. doi:10.1093/aob/mch099

Dwyer, L.M., M. Tollenaar, and L. Houwing. 1991. A nondestructive method to monitor leaf greenness in corn. Can. J. Plant Sci. 71:505-509. doi:10.4141/cjps91-070

Eck, H.B. 1984. Irrigated corn yield response to nitrogen and water. Agron. J. 76:421-428. doi:10.2134/agronj1984.00021962007600030014x

Fernández, F.G., D.B. Mengel, and J.E. Sawyer. 2011. Some things to consider for shallow placement of anhydrous ammonia. Proceedings of the 2011 Wisconsin Crop Management Conference, Madison, WI. Vol. 50. 11-13 Jan. 2011. Coop. Ext. Univ. of Wisconsin-Extension and College of Agric. and Life Sci., Univ. of Wisconsin-Madison, Madison. p. 139-147.

Fink, R.J., and D. Wesley. 1974. Corn yield as affected by fertilization and tillage system. Agron. J. 66:70-71. doi:10.2134/agronj1974.00021962006 600010019x

Foster, T.J., and D.B. Mengel. 2012a. The use of nitrification inhibitors with anhydrous ammonia in no-till corn. Kansas Fertilizer Research 2012. Report of progress 1085. Kansas State Univ., Manahattan. www.ksre.ksu. edu/bookstore/pubs/SRP1085.pdf (accessed 23 May 2013). p. 33-38.

Foster, T.J., and D.B. Mengel. 2012b. Use of nitrification inhibitors with anhydrous ammonia in no-till winter wheat. Kansas Fertilizer Research 2012. Report of progress 1085. Kansas State Univ., Manahattan. www.ksre.ksu. edu/bookstore/pubs/SRP1085.pdf (accessed 23 May 2013) p. 39-43.

Gilmore, E.C., Jr., and J.S. Rogers. 1958. Heat units as a method of measuring maturity in corn. Agron. J. 50:611-615. doi:10.2134/agronj1958.00021 $962005000100014 x$

Hanna, H.M., P.M. Boyd, J.L. Baker, and T.S. Colvin. 2005. Anhydrous ammonia application losses using single-disc and knife fertilizer injectors. Appl. Eng. Agric. 21:573-578. doi:10.13031/2013.18564

Hoeft, R.G., E.D. Nafziger, R.R. Johnson, and S.R. Aldrich. 2000. Modern corn and soybean production. 1st ed. MCSP Publ., Champaign, IL.

Huggins, D.R., and W.L. Pan. 1993. Nitrogen efficiency component analysis: An evaluation of cropping system differences in productivity. Agron. J. 85:898-905. doi:10.2134/agronj1993.00021962008500040022x

IFA. 2013. Fertilizer consumption statistics. Int. Fertilizer Industry Assoc., Paris, France. www.fertilizer.org/ifa/ifadata/search (accessed 24 Apr. 2013).

Iowa State Univeristy. 2013. N rate calculator. Iowa State Univ., Agronomy Ext., Ames. http://extension.agron.iastate.edu/soilfertility/nrate.aspx (accessed 17 May 2013).

John Deere. 2008. John Deere introduces new line of 2510 nutrient applicators. John Deere. www.bcsclients.com/email/jd/20080807/08/index. html (accessed 4 Apr. 2013).

John Deere. 2013a. 2510H Nutrient applicator. John Deere. www.deere.com/ wps/dcom/en_US/products/equipment/nutrient_application/nutrient_applicators/2510h/2510h.page (accessed 22 Mar. 2013). 
John Deere. 2013b. John Deere StarFire RTK system. John Deere. www.deere. com/wps/dcom/en_US/products/equipment/ag_management_solutions/displays_and_receivers/starfire_rtk/starfire_rtk.page (accessed 23 May 2013).

Lauer, J.G., and M. Rankin. 2004. Corn response to within row plant spacing variation. Agron. J. 96:1464-1468. doi:10.2134/agronj2004.1464

Liu, W., M. Tollenaar, G. Stewart, and W. Deen. 2004a. Impact of planter type, planting speed, and tillage on stand uniformity and yield of corn. Agron. J. 96:1668-1672. doi:10.2134/agronj2004.1668

Liu, W., M. Tollenaar, G. Stewart, and W. Deen. 2004b. Response of corn grain yield to spatial and temporal variability in emergence. Crop Sci. 44:847-850. doi:10.2135/cropsci2004.0847

Liu, W., M. Tollenaar, G. Stewart, and W. Deen. 2004c. Within-row plant spacing variability does not affect corn yield. Agron. J. 96:275-280. doi:10.2134/agronj2004.2750

McDowell, L.L., and G.E. Smith. 1958. The retention and reactions of anhydrous ammonia on different soil types. Soil Sci. Soc. Am. J. 22:38-42. doi:10.2136/sssaj1958.03615995002200010012x

Mengel, D.B., D.W. Nelson, and D.M. Huber. 1982. Placement of nitrogen fertilizers for no-till and conventional till corn. Agron. J. 74:515-518. doi:10.2134/agronj1982.00021962007400030026x

Monsanto Technology Development. 2013. Establishing a desired corn stand. Euroke Seeds. www.eurekaseeds.com/pdf/links/agronomic_spotlight/ Agronomic\%20Spotlight\%20Establishing+a+Desired+Corn+Stand. pdf (accessed 18 Jan. 2014)

Nafziger, E.D., P.R. Carter, and E.E. Graham. 1991. Response of corn to uneven emergence. Crop Sci. 31:811-815. doi:10.2135/cropsci1991.001 1183 X003100030053x

NeSmith, D.S., and J.T. Ritchie. 1992. Effects of soil water-deficits during tassel emergence on development and yield component of maize (Zea mays). Field Crops Res. 28:251-256. doi:10.1016/0378-4290(92)90044-A

Nielsen, R.L. 2006. Stand establishment variability in corn. Proceedings of the 2006 Indiana CCA Conference, Indianapolis, IN. Purdue Univ. www. agry.purdue.edu/CCA/2006/ (accessed 27 Apr. 2011).

Rankin, M. 2013. Anhydrous ammonia-Consideration for use. Univ. of Wisconsin Ext. www.uwex.edu/ces/crops/anhyamm.htm (accessed 3 Oct. 2013).

Rossini, M.A., C.A. Maddonni, and M.E. Otegui. 2011. Inter-plant competition for resources in maize crops grown under contrasting nitrogen supply and density: Variability in plant and ear growth. Field Crops Res. 121:373-380. doi:10.1016/j.fcr.2011.01.003

Roth, J.A., I.A. Ciampitti, and T.J. Vyn. 2013. Physiological evaluations of recent drought-tolerant maize hybrids at varying stress levels. Agron. J. 105:1129-1141. doi:10.2134/agronj2013.0066

Sawyer, J. 2013. Apply nitrogen or plant corn? Integrated Crop Management News. Iowa State Univ. Ext. and Outreach. 8 May 2013. www.extension. iastate.edu/CropNews/2013/Issues/20130513.htm\#article4 (accessed 3 Oct. 2013).

Sawyer, J., D. Barker, and M. Hanna. 2009. Crop response to shallow placement of anhydrous ammonia in corn: Project Report-2009 Crop Year. Iowa State Univ., Ames. www.agronext.iastate.edu/soilfertility/info/ ShallowAmmoniaProject.pdf (accessed 17 May 2013).

Schussler, J.R., and M.E. Westgate. 1994. Increasing assimilate reserves does not prevent kernel abortion at low water potential in maize. Crop Sci. 34:1569-1576. doi:10.2135/cropsci1994.0011183X003400060028x

Sohn, J.B., and M. Peech. 1958. Retention and fixation of ammonia by soils. Soil Sci. 85:1-9. doi:10.1097/00010694-195801000-00001
Sommer, S.G., and B.T. Christensen. 1992. Ammonia volatilization after injection of anhydrous ammonia into arable soils of different moisture levels. Plant Soil 142:143-146.

Stamper, J.D. 2009. Evaluation of method of placement, timing and rate of application for anhydrous ammonia in no-till corn production. M.Sc. thesis. College of Agriculture Dep. of Agronomy, Kansas State Univ., Manhattan.

Stanley, F.A., and G.E. Smith. 1956. Effect of soil moisture and depth of application on retention of anhydrous ammonia. Soil Sci. Soc. Am. J. 20:557561. doi:10.2136/sssaj1956.03615995002000040026x

Swart, C.L., L.S. Murphy, and C.W. Swallow. 1971. Retention patterns and effectiveness of anhydrous ammonia applied with undercutting blade. Agron. J. 63:881-884. doi:10.2134/agronj1971.00021962006300060 $017 \mathrm{x}$

Thung, M., D.M. Soares, H. Aidar, and J. Klutchouski. 2007. Increasing bean yield through site-specific cultural practices and adapted lines under central pivot irrigation system in the tropics. Annual report of the Bean Improvement Cooperative 50:197-198.

Tollenaar, M., and E.A. Lee. 2010. Startegies for enchancing grain yield in maize. Plant Breed. Rev. 34:37-82.

Vetsch, J.A., and G.W. Randall. 2004. Corn production as affected by nitrogen application timing and tillage. Agron. J. 96:502-509. doi:10.2134/ agronj2004.0502

Vyn, T.J., and T. West. 2009. GPS-guided systems open new management options for corn producers. Fluid J. 17(3):1-5. Purdue Univ. www. agry.purdue.edu/staffbio/Fluid\%20Journal\%20Late\%20Spring\%20 TVyn\%20LS09-A2.pdf (accessed 2 June 2013).

Wagner, R.C., and E.H. Vasey. 1979. Anhydrous ammonia-Its use? (Circular SF-661. August 1979. Coop. Ext. Serv., North Dakota State Univ., Fargo. http://library.ndsu.edu/tools/dspace/load/?file=/repository/bitstream $/$ handle $/ 10365 / 17686 /$ SF-661-1979.pdf?sequence $=2$ (accessed 2 May 2013).

West, T.D., D.R. Griffith, G.C. Steinhardt, E.J. Kladivko, and S.D. Parsons. 1996. Effect of tillage and rotation on agronomic performance of corn and soybean: Twenty-year study on dark silty clay loam soil. J. Prod. Agric. 9:241-248. doi:10.2134/jpa1996.0241

Westgate, M.E., and J.S. Boyer. 1985. Carbohydrate reserves and reproductive development at low leaf water potentials in maize. Crop Sci. 25:762-769. doi: $10.2135 /$ cropsci1985.0011183X0025000500010x

Wyckoff, M.R. 2009. Evaluation of anhydrous ammonia applications in winter wheat. M.Sc. thesis. College of Agriculture Dep. of Agronomy, Kansas State Univ., Manhattan.

Zhang, J., A.M. Blackmer, and T.M. Blackmer. 2009. Reliability of chlorophyll meter measurements prior to corn silking as affected by the leaf change problem. Commun. Soil Sci. Plant Anal. 40:2087-2093. doi:10.1080/00103620902960609

Zhang, J., A.M. Blackmer, T.M. Blackmer, and P.M. Kyveryga. 2010a. Fertilizer bands and dual effects of nitrogen on young corn plants. Better Crops 94(2):17-19.

Zhang, J., A.M. Blackmer, T.M. Blackmer, and P.M. Kyveryga. 2010b. Fertilizer bands affect early growth of corn. Commun. Soil Sci. Plant Anal. 41:1306-1314. doi:10.1080/00103621003759312

Zhang, J., A.M. Blackmer, J.W. Ellsworth, and K.J. Koehler. 2008a. Sensitivity of chlorophyll meters for diagnosing nitrogen deficiencies of corn in production agriculture. Agron. J. 100:543-550. doi:10.2134/ agronj2006.0153

Zhang, J., A.M. Blackmer, P.M. Kyveryga, B.W. Van De Woestyne, and T.M. Blackmer. 2008b. Fertilizer-induced advances on corn growth stage and quantitative definitions of nitrogen deficiencies. Pedosphere 18:60-68. doi:10.1016/S1002-0160(07)60103-9 